\title{
Discovering Turkish Generation-Z in the Context of Educational Technology
}

\author{
Vehbi Aytekin Sanalan (Corresponding Author) \\ Department of Computer Education and Instructional Technologies \\ Erzincan Binali Yildirim University, Erzincan, Turkey \\ E-mail: sanalan@erzincan.edu.tr
}

Elif Taşlıbeyaz

Department of Computer Education and Instructional Technologies

Erzincan Binali Yildirim University, Erzincan, Turkey

E-mail: etaslibeyaz@erzincan.edu.tr

\author{
Received: August 20, 2020 Accepted: October 13, 2020 Published: October 26, 2020 \\ doi:10.5296/jei.v6i2.17552 URL: https://doi.org/10.5296/jei.v6i2.17552
}

\begin{abstract}
The main aim of this study was to investigate the new generation in order to identify their distinctive characteristics considering their everyday technology use during their lifespan. The secondary aim was to examine the needs of individuals in the Generation- $Z$ in educational environments equipped with technology. A mixed-method research design was utilized. Data were collected by the New Generation Characteristics Scale (NGCS), and by an interview form. The participants of this study were 882 university students. The quantitative data were analyzed using descriptive and inferential techniques, and the qualitative data using content analysis. As a result, participants' internet and social media use frequency was found to be related with their NGCS scores. Internet use from childhood was also found to be an important characteristic for Generation-Z. On the other hand, socio economical statuses were not effective in identifying Generation- $Z$ members. In addition, it was seen that interactive technological applications should be included in the courses in which students can work in collaboration. The students preferred interactive technologies and applications, supporting multitasking features of Generation-Z. In addition, the students wanted to see the availability of more flexible environments, such as online discussions and access to materials outside the classroom. In this study, Generation-Z was more open to cooperation, and they had higher
\end{abstract}


communication skills, which is consistent with previous research.

Keywords: Generation-Z, New generation, Millennial, Educational technology, New generation characteristics scale, Internet use

\section{Introduction}

Many developments affecting the world, such as industry, globalization and information technologies have changed the lives in every age group from past to present. Each era has also formed their unique generation with common characteristics, beliefs, and lifestyles (Saritas \& Barutcu, 2016). Members of different generations have communication barriers due to changing life conditions over the years and this creates a generation gap.

A generation is described as an identifiable group of people who share a distinct set of features, values and significant historical events at their critical development stage (Jones, Ramanau, Cross, \& Healing, 2010). When the generations are evaluated from past to present; "the traditional Generation" or "silent generation" describes a group of individuals born between 1925 and 1946, consisting of people who have features including believing in a common purpose and submission to authority. The "baby boomers generation" was born between 1946 and 1964 and has features such as being idealistic, optimistic and believing in importance of teamwork. Generation-X identifies individuals born between 1965 and 1980, who are more educated, more hard-working, realist, and more diligent than their parents, and are able to use technology for their day-to-day work even though they were born before the age of technology (Adiguzel, Batur, \& Eksili, 2014; Altunbay \& Bicak, 2018; Cetin \& Karalar, 2016). Generation Y (or millennials), people were born in the mid-1980s and1990s. The members of this generation are entrepreneurial, demanding, caring for individuality and technologically dependent, and able to use technological opportunities in business and social life easily (Ayhun, 2013; Kavalci \& Unal, 2016). The most recent Generation-Z comprises those individuals born after the mid-1990s to the early 2000s (Rosen, 2010).

The question of whether digital natives or net Generation is an appropriate description of the new generation is already left behind according to the literature. Many researchers report the new generation having sufficiently different needs and tendencies, as well as other features that make a group of individuals a distinct generation. On the other hand, from the term first coined by (Prensky, 2001) to date, there has been an ambiguity concerning how digital natives differ from the net generation. There is a dedicated body of literature written about digital natives and digital immigrants, and how their overall use of information and communication technologies (ICT) differs from that of their predecessors. Teo (2013) developed a scale to determine a person's tendency towards using ICTs based on their self-perception. According to this study and others using the digital native scale, there is empirical evidence that defines four factors related to being a digital native, even though some earlier studies were hesitant to recognize these factors as determinant specific to digital natives. Being a digital native seems to be a measure of the level of technology adaption, and as revealed in the literature, it has nothing to do with age, which is an identifier for a Generation. Dimock (2019) stated that there was a new generation after millennials, and used the term "post-millennials". Although there is no exact birth date for its members, there is an 
age range for a generation that is considered to be different from the former generation.

First, an effort is required to reveal whether individuals of Generation- $Z$ are different from those of other generations. Furthermore, it is important to uncover the critical features that make Generation- $Z$ unique. Many studies in the literature have been thoroughly examined the young in an attempt to define the new Generation. Numerous studies list the characteristics of the individuals (Giunta, 2017; Hutagalung, 2016; Strauss \& Howe, 1991) such as the consumer behaviours, their behaviour in business life, their learning styles in educational environments, features of social media usage, and other critical features (Kennedy et al., 2008; Quinn \& Oldmeadow, 2013; Thompson, 2013). A number of articles claim that Generation-Z has a tendency to use technology more often (Kennedy, Judd, Dalgarno, \& Walcott, 2010) for different purposes (Jones et al., 2010). Even though Romero, Guitert, Sangrà, and Bullen (2013) found a weak relationship between age and technology use among university students, there is not a clear connection between being a member of the new generation and the birth date. It can be reasoned that the members of this generation should have grown up in an environment in which technology is used extensively. This raises the argument that the new generation differs in technology use besides other distinct characteristics; not only were they born after a certain date but they also experienced being growing up in a technology rich environment at their critical developmental stage.

Nowadays students newly arriving at university have different habits of using technology and needs in their educational lives, as well as in their social lives; therefore, it is necessary to find new methods and uses of technology in educational settings to effectively meet these students' learning needs by discovering their views about learning environments. Thus, the question of how to approach and adapt to these changes in the digital age becomes important for the policymakers and educational institutions (Parlak, 2017; Taskiran, 2017). There are studies in the literature on the use of technology in educational environments for Generation-Z, but only a few concentrate on the assessments of Generation-Z regarding their current utilisation of educational technologies and their expectations for learning environments. Understanding the current situation and expectations about educational technology of the generation is important to determine what needs to be done, and taking into account the students' views about course design will shed light on planning the activities in future courses.

The main aim of this study was to investigate the new generation in order to identify their distinctive characteristics considering their everyday technology use during their lifespan. The secondary aim of the study was to examine the needs of Generation- $Z$ individuals in technology-rich educational environments. The results of this study contribute to the literature by clarifying controversial view of whether Generation- $Z$ is a separate cohort or a young form of digital natives. The results can also offer guidance to those conducting studies on the characteristics of individuals in Generation- $Z$ especially concerning the design of educational environments. The research questions of the study were;

- What are the common critical characteristics of current university students about technology use and demographics? 


\section{Macrothink}

- What is the relationship between technology use and living in a technology-rich environment as a description of Generation-Z?

- What are current students' views on the use of digital technology in classrooms?

- What are current students' ideas about how a course should be designed?

\section{Method}

\subsection{Research Design}

A mixed-method research design was used, which serves both quantitative and qualitative research purposes (Calik \& Sözbilir, 2014). The quantitative data were collected by the New Generation Characteristics Scale (NGCS) in attachment, which was created, applied and analyzed. Ten students, showing the characteristics of Generation-Z, were determined by their scale scores, and eight of these students participated in the interviews. The qualitative data of the study were also collected by an interview form.

\subsection{Participants}

The participants of this study were 882 students at a university in Turkey in the 2018-2019 academic year. Fifty percent of the participants were female and $45 \%$ were male while the remaining $5 \%$ refrained to give gender information. The students were from different departments. These participants were asked to fill in NGCS online. Initially, 10 students were selected using the criterion sampling method using the total scores in NGCS. Firstly, an e-mail was sent to these 10 students who had scores at least three standard deviations higher than the sample mean $(\mathrm{z}>+3.0,99.9 \%)$, to invite them to participate in the interview voluntarily. The rationale in selecting the top scorers is because to gather deeper information about the generation's educational technology preferences. Eight of the students who responded positively and gave consent were interviewed. The students' distribution by departments is shown in Table 1.

Table 1. Departments of the interviewed students

\begin{tabular}{|l|l|l|}
\hline Faculty & Department & $f$ \\
\hline \multirow{2}{*}{ Education Faculty } & Computer and Instructional Technology & 5 \\
\cline { 2 - 3 } & Primary School Teaching & 1 \\
\hline Engineering Faculty & Mechanical Engineering & 2 \\
\hline
\end{tabular}

\subsection{Data Collection Instruments}

\subsubsection{NGCS}

A 45-item pool was created from the relevant literature to develop the draft version of NGCS (Dimock, 2019; Prensky, 2001; Rosen, 2010; Taslibeyaz, 2019; Teo, 2013). These items were 
reviewed and some were revised by the experts to provide language clarity and validity. In order to ensure content validity, the items in the draft scale were evaluated by four researchers, two of whom were experts in computer and instructional technologies and the other two in measurement and evaluation.

The number of items on the scale was reduced to 43 according to expert opinion. Three questions were added to this scale in a section concerning demographic information, and internet and social media usage. The items in the draft scale were rated from 1 (strongly disagree) to 5 (strongly agree).

\subsection{Reliability}

The data obtained from the draft scale was analysed using SPSS statistical program v. 16.0 after the pilot implementation. The Cronbach alpha reliability value of the scale was calculated as .92. Moreover, an inter-item correlation matrix was created to examine the correlation between the items and correlations in the scale. The items with high correlation coefficients were eliminated. The reliability coefficient of the final scale was determined as .93 .

\subsection{Validity}

The data were analyzed using SPSS v. 16.0 for validity analyses. Validity is established by expert reviews. Factor analysis was used to test the construct validity of the scale. No sub-factor was obtained as result of the factor analysis. An exploratory factor analysis is carried out after KMO coefficient and the Barlett Sphericity test for basic component analysis.

\subsection{Interview Form}

The researchers prepared an interview form to collect data about expected educational technologies to be used in the classroom. A subject area expert and a language expert checked the interview form. The form then revised to allow elaborating answers. The questions were enriched with additional enquiries to obtain more information from each student during the interview. In the interview form, the students were asked to respond to seven questions about the current situation, expectations, and course design for the use of technology in educational environments. The interviews were voice-recorded with the participants' consent.

\subsection{Data Analysis}

Both descriptive and inferential analysis techniques were employed in this study. The frequencies and central tendency scores were calculated and reported. Hypothesis testing was carried out by one-way analysis of variance. The assumptions were checked against violation and found to be robust. The alpha was limited to .05 for all tests. The qualitative data obtained from the interviews were analyzed using descriptive content analysis.

\section{Results}

The participants voluntarily completed the online questionnaire within two weeks. The descriptive analysis showed that the students were between 19-27 years old with a median 
age of 22 years. The distribution of the class levels of the participants was as follows: freshmen $37 \%$, sophomore $26 \%$, junior $16 \%$, and senior $17 \%$. Most of the students were from families of middle class socioeconomic status (SES) (72\%), with students from low- and high-income families also present in the sample (15\% and $13 \%$, respectively).

\subsection{Demographic Characteristics of Generation- $Z$}

The following two demographic questions in the scale revealed interesting results: "Was the internet available at home when you were born?" and "Have you regularly used the internet at home since your childhood?". These questions were asked in order to determine the age of the Generation- $Z$ individuals when they first encountered the internet. The findings and frequency of responses are shown in Table 2 .

Table 2. Percentages of having internet connection and regular use of internet since childhood

\begin{tabular}{|l|l|l|}
\hline Item & Yes & No \\
\hline Internet connection existing when they were born & 7 & 93 \\
\hline Regular use of internet since childhood & 19 & 81 \\
\hline
\end{tabular}

The results showed that a greater percent of participants lacked a dedicated internet connection at home when they were born; however, a slightly larger proportion regularly used the internet. Since the participants' median age was 22 years, we can assume that some did have internet access in the early 2000s. According to the Turkish Statistical Institute (2019) data, the number of household internet connection subscribers started increasing in 2006 (Figure 1). We can conclude that very few participants must have had internet connection when they were born.

When the household internet subscribers started to increase in 2006, the participants were possibly at least pre-schoolers (3-5 years old). Table 3 shows the demographical data concerning the reported average daily internet usage (Table 3).

Table 3. Perceived internet use frequency per day

\begin{tabular}{|l|l|l|}
\hline & $\mathrm{f}$ & $\%$ \\
\hline Less than an hour & 75 & 8.5 \\
\hline 1 to 3 hours & 345 & 39.1 \\
\hline 4 to 6 hours & 305 & 34.6 \\
\hline $7+$ hours & 157 & 17.8 \\
\hline
\end{tabular}




\section{Macrothink}

Regarding the frequency of the internet use, the results (Table 3) show that the majority of students used Internet moderately, while a considerable number engaged in heavy use. The internet usage rate was about $73 \%$ when it comes to 1 to 6 hours of use. Seventeen percent of the students used the internet for seven hours or more while $8.5 \%$ used it for less than one hour.

Another demographic finding obtained from the data relates to how often students checked their social media per hour. Since Generation-Z tends to use social media frequently, we asked how many times they checked their social media account per hour. The results are given in Table 4.

Table 4. Frequency of checking social media account

\begin{tabular}{|l|l|l|}
\hline & $\mathrm{f}$ & $\%$ \\
\hline Seldom & 271 & 30.7 \\
\hline 1 to 5 times & 322 & 36.5 \\
\hline 6 to 10 times & 130 & 14.7 \\
\hline 11 to 15 times & 73 & 8.3 \\
\hline 16 to 20 times & 25 & 2.8 \\
\hline $20+$ times & 61 & 6.9 \\
\hline
\end{tabular}

According to Table 4, one-third of the participants reported that they seldom checked their social account (30.7\%). Another one-third (36.5\%) also checked their account for updates one to five times per hour. In addition, about $70 \%$ of the participants checked their social media account at least once every hour.

\subsection{Relationship between NGCS Scores and Demographic Characteristics}

The first finding about the relationship between NGCS scores and demographic characteristics was related to the socioeconomic status level of the individuals and their scores in the light of the data obtained from the scale. The relationship between the socioeconomic levels of the scores obtained from NGCS was examined. The results are given in Table 5. 


\section{Al Macrothink}

Table 5. Participants' NGCS scores means and standard deviations by NGCS scores by SES levels

\begin{tabular}{|l|l|l|l|l|}
\hline SES level & N & M & SD & F Value \\
\hline Low & 130 & 146.55 & 40.02 & $2.754^{*}$ \\
\hline Medium & 637 & 152.90 & 30.40 & \\
\hline High & 115 & 155.69 & 35.03 & \\
\hline
\end{tabular}

Note. ${ }^{*} p>.05 .+$ SES: Socioeconomic status.

According to the results in Table 5, no significant relationship was found between the socioeconomic levels of the individuals in the Generation- $Z$ and the scores obtained from NGCS.

The second finding was related to the difference between the NGCS scores of individuals who had internet at home when they were born and those who did not. For this purpose, the mean NGCS scores were compared between the two groups as shown in Table 6 .

Table 6. Participants' NGCS scores means and standard deviations by having internet at home when born

\begin{tabular}{|l|l|l|l|l|}
\hline & $\mathrm{N}$ & $\mathrm{M}$ & $\mathrm{SD}$ & $\mathrm{t}$ \\
\hline Yes & 60 & 153.41 & 30.60 & $1.089^{*}$ \\
\hline No & 822 & 152.24 & 32.82 & \\
\hline
\end{tabular}

Note. ${ }^{*} p>.05$.

According to the results in Table 6, no significant relationship was found between having internet when born and higher scores from NGCS among members of Generation-Z.

The third finding of the study concerned the relationship between the individuals' internet use since childhood and the scores obtained from the scale. The results show that the participants with internet access from childhood had significantly higher scores, displaying more Generation-Z characteristics than those without access to internet connection (Table 7). 


\section{Macrothink}

Table 7. Participants' NGCS scores means and standard deviations by internet use from childhood

\begin{tabular}{|l|l|l|l|l|}
\hline & N & M & SD & t \\
\hline Yes & 164 & 165.05 & 27.91 & $17.71^{*}$ \\
\hline No & 718 & 149.42 & 32.99 & \\
\hline
\end{tabular}

Note. ${ }^{*} p<.05$.

The fourth finding of the study was about the relationship between the daily use of internet (in hours) and the scores obtained from the scale. The results showed that the participants had significantly higher scores as their average use of internet increased up to 12 hours per day (Table 8).

Table 8. Participants' NGCS scores means and standard deviations by average use of internet

\begin{tabular}{|l|l|l|l|l|}
\hline & N & M & SD & F Value \\
\hline Less than one hour & 75 & 135.09 & 34.15 & $8.392^{*}$ \\
\hline $1-3$ hour & 345 & 144.14 & 34.18 & \\
\hline 4-6 hour & 305 & 158.80 & 27.74 & \\
\hline 7-9 hour & 95 & 166.66 & 27.27 & \\
\hline $10-12$ hour & 30 & 171.26 & 23.65 & \\
\hline More than 13 hours & 32 & 158.90 & 36.69 & \\
\hline
\end{tabular}

Note. ${ }^{*} p<.05$.

The post-hoc analysis revealed two subsets of daily usage. The first group was composed of participants who used the internet 0-3 hours per day. The second group used the internet 4-12 hours per day. These two groups differed in their average NGCS scores.

The fifth finding was about the relationship between the frequency of checking social media accounts per hour and the scores obtained from the scale. The results are presented in Table 9. 


\section{Macrothink}

Table 9. Participants' NGCS scores means and standard deviations by frequency of checking social media account

\begin{tabular}{|l|l|l|l|l|}
\hline & N & M & SD & F Value \\
\hline Seldom & 271 & 140.86 & 33.54 & $5.586^{*}$ \\
\hline $1-5$ times & 322 & 152.78 & 29.73 & \\
\hline $6-10$ times & 130 & 160.46 & 32.10 & \\
\hline $11-15$ times & 73 & 160.54 & 34.73 & \\
\hline $16-20$ times & 25 & 165.92 & 18.76 & \\
\hline $20+$ times & 61 & 168.09 & 30.35 & \\
\hline
\end{tabular}

Note. ${ }^{*} p<.05$.

There was a relationship between the number of times the students checked their social media accounts and their NGCS scores (Table 9). The results showed that there were differences in how often the students checked their social media accounts per hour. The more the students checked their social media, the higher they showed Generation- $Z$ characteristics. The post-hoc analysis revealed three groups that significantly differed from each other.

The last finding was about the differences in the NGCS scores of individuals. All findings about demographic characteristics were examined together, and the results are shown in Table 10 .

Table 10. Differences in NGCS scores according to the availability and use of technology

\begin{tabular}{|l|l|}
\hline Variable & F Value \\
\hline SES & 2.754 \\
\hline Having internet when born & .071 \\
\hline Use internet since childhood & $31.638^{*}$ \\
\hline Average use of internet & $18.513^{*}$ \\
\hline Checking social media & $13.882^{*}$ \\
\hline
\end{tabular}

Note. ${ }^{*} p<.05$.

The basic characteristics of Generation-Z include SES, having an internet connection from birth, internet use from childhood, average use of internet, and frequency of checking social media accounts. The results showed that SES was not a factor that differentiated the NGCS 
scores of the participants.

\subsection{Students'Views on Use of Technology in Educational Environments}

\subsubsection{Duration of Technology Use During the Lesson}

Concerning the duration of the use of technological tools in the lessons, the students stated that in theoretical lessons, from the beginning to the end of the course, PowerPoint presentations were made $(f=5)$. In addition, technological tools were used when needed (such as watching videos) $(f=3)$. Overall on average, the technological tools were used for 20 minutes in the courses.

\subsubsection{Features of an Effective Learning Environments}

One of the interview and the components to be included were obtained. The students suggested including interactive activities, online midterm exams, and keeping the student active in the lessons $(f=8)$. They also made comments on the use of internet access and digital tools to increase motivation and enable peer learning $(f=2)$.

The students stated that there should be flexible learning environments in which they could access the course materials and participate in the discussions $(f=5)$. The applications that the students preferred to use were in the form of competitions with Kahoot!, presentations with Prezi, giving and collecting assignments from social media, and performing mid-term exams online $(f=9)$. The students preferred more engaging interactive applications and more flexible methods in lessons. They also mentioned that three-dimensional simulations and virtual reality applications that should provide them with real-life experience should be included. Online mid-term examinations and discussion platforms were also seen as having a positive effect $(f=1)$.

\section{Discussion}

\subsection{Demographic Features of Generation-Z}

The first finding of the study was related to the demographic characteristics of the participants. For most of the participants, there was no internet connection in their home when they were born; however, their NGCS scores did not significantly differ compared to those having internet connection at home at that time. This finding can be considered tangible considering the students' ages. In Turkey, widespread, consistent internet connectivity has been available since 2006 . This is the year when our participants were mostly pre-schoolers, and it is only logical that they would not have an internet connection at home. However, in the literature, there is no clear consensus on the date of birth of Generation- $Z$ with some studies describing the birth dates as in the mid-2000s, while others considering it to be the mid-90s. This may be due to countries having entered the digital age later and also the proliferation of the internet. Horn et al. (2013) gave the dates as the mid-90s, while (Kirik \& Koyustu, 2018) and (Tuncer \& Tuncer, 2016) suggested that it was the 2000s. This difference may be due to the commercial spread of the internet access across the world beginning in 1995. However, the widespread of use of the internet in Turkey began in 2006 (Figure 1); thus, internet access at home at the time of birth does not signify that a person is a member of 


\section{MlMacrothink}

Generation-Z; people who have internet at home when they were born did not participate in the present study since they were in their mid-teens at the time of the study. On the other hand, the participants who had been using the internet since childhood showed statistically significant Generation- $Z$ characteristics (Table 1). This complies with previous findings. The participants of the study were pre-schoolers in 2006, and thus it can be considered that those that had used the internet since childhood showed distinctive characteristics of Generation-Z.

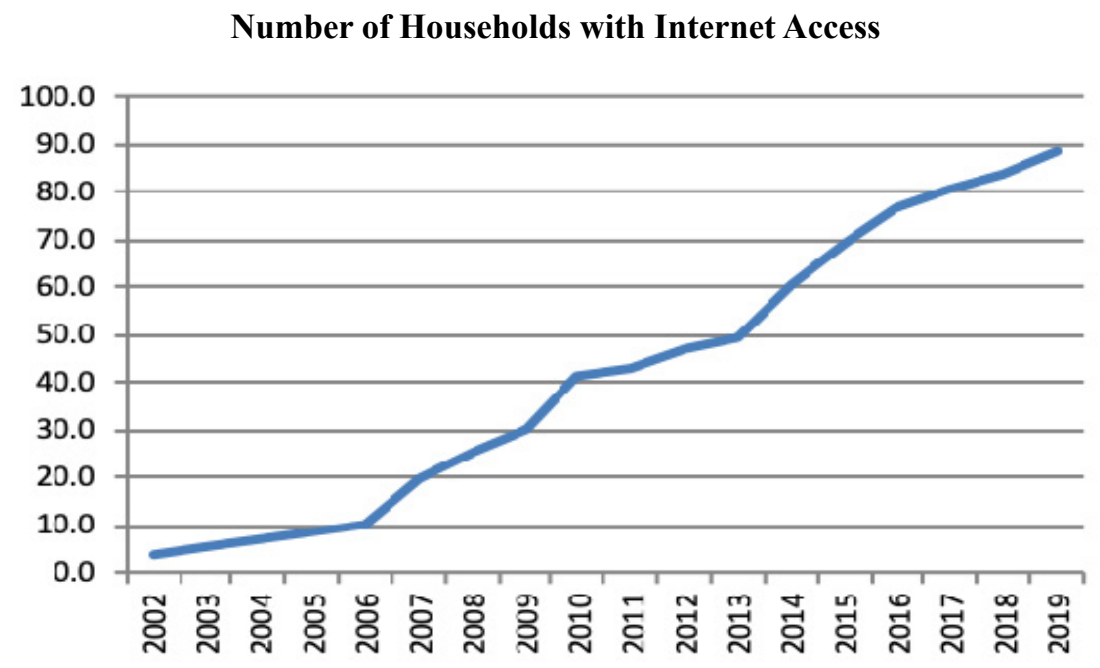

Figure 1. Households with internet access by year

The regular use of the internet by the participants is the most significant characteristic of Generation-Z. It was found that the majority of these participants spent at least three to four hours a day on the internet. There was a significant relationship between the internet use frequency and NGCS score. One reason may be that the students perform almost all their daily work over the internet according to the studies in the literature (Golovinski, 2011; Kavalci \& Unal, 2016; Yelkikalan, Akatay, \& Altin, 2010). Generation-Z even prefers the virtual world completely over the physical one instead of separating the two (Sladek \& Grabinger, 2014). Another reason can be that these individuals have been familiar with digital/online environment from an early age and their social environments are maintained through this platform (Karahisar, 2013; Kirik \& Koyustu, 2018; Sonmez, 2019). They can undertake their daily tasks easily and quickly and maintain their friendship relationships in digital/online environments (Altunbay \& Bicak, 2018; Kennedy, Judd, Churchward, Gray, \& Krause, 2008).

Another important finding obtained from the study was the number of times that the participants checked their social media account per hour, revealing a significant relationship between the use frequency of social media and NGCS scores. A significant number of individuals checked their social media accounts once to five times an hour. Studies in the literature indicate that social media integration is quite high among these individuals (Sonmez, 2019; Tuncer \& Tuncer, 2016). In addition to consuming content on social media, individuals 
of Generation- $Z$ are also actively producing content, and many people in this Generation broadcast to millions of followers through video blogs (Kapil \& Roy, 2014). Therefore, our finding strongly suggests that the participants' differences in being a Generation- $Z$ member rely partly on how they use the technology rather than whether they use it.

Another finding of the study was that despite the expectation that students with low SES would have less access to technology, and thus would score lower in NGCS, there was no significant difference in the NGCS scores according to the SES of the participants. This means that being a Generation- $Z$ member is unrelated to the family income or the parents' education. This is particularly important since it shows that being a member of Generation-Z is probably not related to the digital divide, which is correlated to parents' income and education level (Seferoglu, Avci, \& Kalayci, 2008), and dichotomously defines a person's access to technology. This finding is also important in terms of showing that the features of Generation- $Z$ are not related to the digital divide and that the measured features belong to an entire generation. To our best of knowledge, there was no study about the relationship between socioeconomic level and Generation- $Z$ in the literature.

\subsection{Context of Educational Technology}

The finding inferred from the students' enthusiasm for technology use was that it fostered effective participation in the classroom. In this environment, students are more likely to learn since they can interpret information rather than memorise it; thus, they prefer more interactive learning environments. The results of the qualitative analysis revealed that students even led their instructors to adapt technology in the learning process. Individuals in Generation-Z prefer to determine how they can access information, how to interpret the information, and how they can benefit from information instead of wasting time memorising information (Sladek \& Grabinger, 2014). These types of studies are in favour of the integration of technology in the lessons the students attend (Brown \& Czerniewicz, 2010; Kennedy et al, 2008) and the preference to create more interactive environments (Beyers, 2009; Fisher \& Newton, 2014; Hajhashemi, Caltabiano, \& Anderson, 2017; Somyurek, 2014). A further reason for these changes is that learners tend to prefer visual elements rather than written resources, choosing video, pictures, and questions rather than text in digital slides. According to the literature, while the previous Generations learn from written sources, Generation-Z learn better from visual materials (Sladek \& Grabinger, 2014). Online learning, virtual classroom environment, and the use of technological tools are of great importance in the learning process of Generation-Z (Taslibeyaz, 2019; Gramigna, 2015). In addition, positive views have been obtained particularly from engineering students regarding the implementation of real life experiences. However, since it is not always economical and functional to obtain these experiences, virtual reality applications can be utilised (Arici, 2013; Kayabasi, 2002). In this way, the interest in learning can be increased through real life experience.

Another finding was obtained from the analysis of the students' views about what was required to create effective instruction. The students need technology integration in and outside the classroom because they have more than one electronic device (e.g. mobile devices 
and computers) and often use information/communication technologies (Grail Research, 2011). This intense interest of Generation- $Z$ makes technology use inevitable in the education of this Generation (Sonmez, 2019). Positive results for technology integration have been obtained from studies on Generation-Z (Giunta, 2017; Jaleniauskienė \& Jucevičienė, 2015; Somyurek, 2009).

The students in the current study, especially those attending the computer and instructional technologies department also stated that they would like to have collaborative practices in which peer learning could be used for in-class and out-of-class activities for effective instruction. This result can be attributed to Generation- $Z$ gaining more positive results from collaborative learning, being more familiar with working with their peers/groups in the social media environment, and their high communication and group-working skills. In this study, Generation- $Z$ was more open to cooperation, and they had higher communication skills, which is consistent with previous research (Taslibeyaz, 2019; Vogel, 2015).

As a result, it was found that there was no definite interval for the years in which the individuals in Generation- $Z$ were born, and this case is related to the conditions of the country of origin of the individuals. In addition, at the time they were born, internet connection was available in home, and it was found that this case was related to the widespread availability of the internet in Turkey. It was concluded that individuals in Generation- $Z$ had been using the internet regularly from childhood, and this was not related to their SES. The intensive use of the internet was found to be one of the critical features of Generation-Z. In addition, Generation-Z had high levels of internet and social media usage and felt more comfortable expressing themselves in social media environments.

The students believed that the greater use of technology in class activities had a positive effect on their education. The students preferred collaborative and interactive technologies and applications, supporting the multitasking features of Generation-Z. In addition, the students wanted to see the availability of more flexible environments, such as online discussions and access to materials outside the classroom. The applications that could provide real life experiences in the lessons and applications, such as virtual reality for this purpose would provide positive results in terms of the effectiveness of the learning process.

Even if current study was conducted before the pandemic, distance learning became an important tool during the hard times when people practiced social distancing and quarantine due to COVID-19 outbreak. This generation practiced e-learning via information and communication technologies worldwide. It proves important to know the technology use preferences of this generation in designing emergency distance education applications during the pandemic.

\section{Recommendations}

(1) Interactive technological tools and applications should feature more in the lessons.

(2) Flipped classroom environments should be designed wherein students can collaborate online. 
(3) Social online platforms such as video blogs should be included in the lesson content in order to attract students' interests.

(4) Extracurricular activities such as creating web/video blogs should be organised and discussion environments should be created in order to interact with students outside the classroom.

(5) Activities should be featured to encourage peer learning.

(6) Virtual reality applications that provide real life experience should be used in the lessons.

(7) In-service training should be given to instructors within the scope of digital transformation in order to make more use of technological tools in the classroom.

\section{References}

Adiguzel, O., Batur, H. Z., \& Ekşili, N. (2014). Kuşaklarin Değişen Yüzü Vey Kuşaği Ile Ortaya Çikan Yeni Çalişma Tarzi: Mobil Yakalilar. Süleyman Demirel Üniversitesi Sosyal Bilimler Enstitüsü Dergisi, 19, 165-182.

Altunbay, M., \& Bicak, N. (2018). Türkçe Eğitimi Derslerinde “Z Kuşağı” Bireylerine Uygun Teknoloji Tabanlı Uygulamaların Kullanımı. Zeitschrift für die Welt der Türken/Journal of World of Turks, 10(1), 127-142.

Arthur, R. (2016). Generation Z: 10 stats from SXSW you need to know.

Ayhun, S. E. (2013). Kuşaklar arasındaki farklılıklar ve örgütsel yansımaları. Ekonomi ve Yönetim Araştırmaları Dergisi, 2(1), 93-112.

Beyers, R. N. (2009). A five dimensional model for educating the net Generation. Journal of Educational Technology \& Society, 12(4), 218-227.

Bromwich, J. (2018). We asked Generation Z to pick a name: it wasn't Generation Z. The New York Times. The New York Times Company.

Brown, C., \& Czerniewicz, L. (2010). Debunking the 'digital native': beyond digital apartheid, towards digital democracy. Journal of Computer Assisted Learning, 26(5), 357-369. https://doi.org/10.1111/j.1365-2729.2010.00369.x

Cetin, C., \& Karalar, S. (2016). X, Y ve Z Kupaðý Öðrencilerin Çok Yönlü ve Sýnýrsýz Kariyer Algýlarý Üzerine Bir Araptýrma/A Research on Generation X, Y and Z Students' Perceptions of Protean and Boundaryless Career. Çanakkale Onsekiz Mart Üniversitesi Yönetim Bilimleri Dergisi, 14(28), 157.

Dimock, M. (2019). Defining Generations: Where Millennials end and Generation Z begins. Pew Research Center, 17.

Fisher, K., \& Newton, C. (2014). Transforming the twenty-first-century campus to enhance the net-Generation student learning experience: using evidence-based design to determine what works and why in virtual/physical teaching spaces. Higher Education Research \& Development, 33(5), 903-920. https://doi.org/10.1080/07294360.2014.890566 
Giunta, C. (2017). An Emerging Awareness of Generation Z Students for Higher Education Professors. Archives of Business Research, 5(4). https://doi.org/10.14738/abr.54.2962

Golovinski, M. S. (2011). Event 3.0: How Generation $Y \& Z$ are Re-shaping the Events Industry.

Grail Research. (2011). Consumers of tomorrow insights and observations about Generation Z. Retrieved from https://www.slideshare.net/johnyvo/consumers-of-tomorrowinsightsand observationsaboutGenerationz-25226677

Hajhashemi, K., Caltabiano, N., \& Anderson, N. (2017). Net-Geners' perceptions of engagement through online videos. Journal of Computers in Education, 4(3), 321-337. https://doi.org/10.1007/s40692-017-0084-7

Horn, M., Dane, S., Griffith, C., Kimber, J., Marquez, L., Mason, C., ... Reeson, A. (2013). Next Generation broadband: Understanding the impacts, capturing the benefits (Report EP1312233, p. 30). CSIRO, North Ryde, NSW.

Hutagalung, I. (2016). Selective exposure and consumer behavior-Interpretative phenomenological analysis in consumer Behavior of $\mathrm{z}$ Generation adolescent on the ad information of smartphone selection. International Journal of Organizational Innovation, $9(2), 85$.

Jaleniauskienè, E., \& Jucevičienè, P. (2015). Reconsidering university educational environment for the learners of Generation Z. Socialiniai Mokslai, 2, 38-53. https://doi.org/ 10.5755/j01.ss.88.2.12737

Jones, C., Ramanau, R., Cross, S., \& Healing, G. (2010). Net Generation or Digital Natives: Is there a distinct new Generation entering university? Computers \& Education, 54(3), 722-732. https://doi.org/10.1016/j.compedu.2009.09.022

Kapil, Y., \& Roy, A. (2014). Critical evaluation of Generation Z at workplaces. International Journal of Social Relevance \& Concern, 2(1), 10-14.

Karahisar, T. (2013). Dijital Nesil, Dijital İletişim ve Dijitalleşen (!) Türkçe. AJIT-e: Online Academic Journal of Information Technology, 4(12).

Kavalci, K., \& Unal, S. (2016). Y ve Z Kuşaklarının Öğrenme Stilleri ve Tüketici Karar Verme Tarzları Açısından Karşılaştırılması/A Research on Comparing Consumer Decision-Making Styles and Learning Styles in Terms of the Generation Y and Z. Atatürk Üniversitesi Sosyal Bilimler Enstitüsü Dergisi, 20(3).

Kayabasi, Y. (2002). Sanal Gerçekli̇k ve Ĕ̆̇̇tİm Amaçli Kullanilmasi. Turkish Online, 151.

Kennedy, G., Dalgarno, B., Bennett, S., Judd, T., Gray, K., \& Chang, R. (2008). Immigrants and natives: Investigating differences between staff and students' use of technology. Hello! Where are you in the landscape of educational technology (pp. 484-492).

Kennedy, G., Judd, T., Dalgarno, B., \& Waycott, J. (2010). Beyond natives and immigrants: exploring types of net Generation students. Journal of Computer Assisted Learning, 26(5), 
332-343. https://doi.org/10.1111/j.1365-2729.2010.00371.x

Kirik, A. M., \& Koyustu, S. (2018). Z Kuşaği Konusunda Yapilmiş Tezlerin Içerik Analizi Yöntemiyle Incelenmesi. Gümüşhane Üniversitesi Iletişim Fakültesi Elektronik Dergisi, 6(2), 1497-1518. https://doi.org/10.19145/e-gifder.443304

Parlak, B. (2017). Dijital Çağda Eğitim: Olanaklar ve Uygulamalar Üzerine Bir Analiz. Suleyman Demirel University Journal of Faculty of Economics \& Administrative Sciences, 22.

Prensky, M. (2001). Digital natives, digital immigrants part 1. On the Horizon, 9(5), 1-6. https://doi.org/10.1108/10748120110424816

Quinn, S., \& Oldmeadow, J. A. (2013). Is the iGeneration a 'we' Generation? Social networking use among 9- to 13-year-olds and belonging. British Journal of Developmental Psychology, 31(1), 136-142. https://doi.org/10.1111/bjdp.12007

Romero, M., Guitert, M., Sangrà, A., \& Bullen, M. (2013). Do UOC students fit in the Net Generation profile? An approach to their habits in ICT use. The International Review of Research in Open and Distributed Learning, 14(3), 158-181. https://doi.org/10.19173/irrodl. v14i3.1422

Rosen, L. D. (2010). Rewired: Understanding the iGeneration and the way they learn. St. Martin's Press.

Saritas, E., \& Barutcu, S. (2016). Tüketici Davranışlarının Analizinde Kuşaklar: Sosyal Medya Kullanımı Üzerinde Bir Araştırma. Pamukkale Journal of Eurasian Socioeconomic Studies, 3(2), 1-15. https://doi.org/10.5505/pjess.2016.27146

Seferoglu, S. S., Avci, Ü., \& Kalayci, E. (2008). Sayısal Uçurum: Türkiye'deki Durum ve Mücadelede Uygulanabilecek Politikalar. Ulusal Bilişim Kurultayı, 25, 19-21.

Sladek, S., \& Grabinger, A. (2014). Gen Z. Introducing the first Generation of the 21st Century. Retrieved from https://goo gl/Iu5o2t

Somyurek, S. (2014). Öğretim sürecinde z kuşağının dikkatini çekme: artırılmış gerçeklik. Ë̆itim Teknolojisi Kuram ve Uygulama, 4(1), 63-80. https://doi.org/10.17943/etku.88319

Sonmez, F. (2019). Sosyal Medyanın, Z Kuşă̆ı Tüketicilerinin Satın Alma Davranışları Üzerindeki Etkisi. https://doi.org/10.31237/osf.io/jwsgd

Strauss, W., \& Howe, N. (1991). Generations: The history of America's future, 1584 to 2069. William Morrow \& Co.

Taskiran, A. (2017). Dijital çağda yükseköğretim. Açıöğretim Uygulamaları ve Araştırmalarl Dergisi, 3(1), 96-109.

Taslibeyaz, E. (2019). Z Kuşaği Ile Ilgili Araştirma Eğilimlerinin ve Eğitime Yönelik Katkilarinin Analizi. Dokuz Eylül Üniversitesi Sosyal Bilimler Enstitüsü Dergisi, 21(3), 715-729. https://doi.org/10.16953/deusosbil.456533 


\section{Macrothink}

Teo, T. (2013). An initial development and validation of a Digital Natives Assessment Scale (DNAS). Computers \& Education, 67, 51-57. https://doi.org/10.1016/j.compedu.2013.02.012

Thompson, P. (2013). The digital natives as learners: Technology use patterns and approaches to learning. Computers \& Education, 65, 12-33. https://doi.org/10.1016/j.compedu.2012. 12.022

Tuncer, A. İ., \& Tuncer, M. U. (2016). Eğlence reklamlarının viral uygulamaları ve Z kuşağ1 üzerinden bir değerlendirme. TRT Akademi, 1(1), 210-229.

Turkish Statistical Institute. (2019). Information Society Statistics.

Vogel, P. (2015). Generation Jobless? Turning the youth unemployment crisis into opportunity. Houndsmills: Palgrave Macmillan.

Yelkikalan, N., Akatay, A., \& Altın, E. (2010). Yeni girişimcilik modeli ve yeni nesil girişimci profili: Internet girişimciliği ve $Y, M, Z$ kuşă̆l girişimci.

\section{Appendix}

\section{New Generation Characteristics Scale (NGCS) Items}

1. I think I can express myself as I want on the internet.

2. I feel more comfortable online than in real life.

3. I can easily adapt / enjoy participating in new trends on the Internet.

4. It is important for me to have new technological tools.

5. I like exploring new environments on the Internet.

6. New applications published on the internet attract my attention.

7. I have friends that I meet online that are more valuable than my real life friends.

8. I edit my photos before sharing.

9. I edit my videos before uploading.

10. It is important for me that the content I share (tweet, post, video, etc.) is original.

11. I prefer communicating over the internet to real life.

12. The communication style of the generations before me (my elders) is not suitable for me.

13. If I am going to be in teamwork, I prefer to be in teamwork with my friends on the internet instead of real life.

14. I run multiple jobs at the same time without being aware of it.

15. I adopt the virtual world on the internet as much as the real world.

16. I have more friends on social media than they actually are. 
17. I meet new people mostly online.

18. When I wake up, my first job is to check the phone.

19. My phone is at my bedside while lying down.

20. I would like to be connected to the internet $24 / 7$.

21. It is normal for people to differ from what they reflect on social media in real life.

22. When I post a photo, I expect it to be liked.

23. I handle my work with technological tools.

24. I would like to have the latest technological tools.

25. I impress my friends with my posts on the Internet.

26. I share posts I encounter on a sensitive issue concerning the society.

27. My learning needs are different from previous generations.

28. I use new technological tools easily.

29. When I search the Internet, I can immediately access the information I want with the keywords I use.

30. I interpret the information I get from the internet quickly.

31. I think I only have a world of my own on the Internet.

32. It is important for me to be the pioneer of a new trend on the Internet.

33. I use the keyboard quickly and effectively.

34. The information on the internet catches my attention.

35. Information on the Internet is more understandable than real life information.

36. I am willing to use new technological tools.

37. I use the computer every day for entertainment.

38. I can simultaneously check emails and chat online.

39. I listen to music while using the internet for my work.

40. I can communicate with my friends and do my job at the same time.

41. I can use multiple applications on the computer at the same time.

42. While chatting on the phone with a friend, I send another message at the same time.

43. When I want to explain something, I use pictures more than words. 


\section{Copyright Disclaimer}

Copyright for this article is retained by the author(s), with first publication rights granted to the journal.

This is an open-access article distributed under the terms and conditions of the Creative Commons Attribution license (http://creativecommons.org/licenses/by/3.0/). 